\author{
Jurnal IImiah AL-Jauhari (JIAJ) \\ Volume 3 No 1, Juni 2018 \\ ISSN: $2541-3430$ \\ E-ISSN: 2541-3449 \\ Halaman 33-48
}

\title{
Penerapan Reward and Punishment melalui Tata Tertib Sistem Point dalam Meningkatkan Kualitas Pendidikan Karakter
}

\author{
Oleh: \\ Yon Gani
}

\begin{abstract}
Abstrak
Dalam UU Sisdiknas No. 20 tahun 2003 pasal 1 ayat 1 bahwa Pendidikan adalah usaha sadar dan terencana untuk mewujudkan suasana belajar dan proses pembelajaran agar peserta didik secara aktif mengembangkan potensi dirinya untuk memiliki kekuatan spiritual keagamaan, pengendalian diri, kepribadian, kecerdasan, akhlak mulia, serta keterampilan yang diperlukan dirinya, masyarakat, bangsa dan Negara. Namun fakta di lapangan menunjukkan masih banyak permasalahan yang jauh dari harapan baik itu dari peserta didik Penyimpangan berbagai norma agama dan sosial kemasyarakatan dalam bentuk kurang hormat pada guru dan pegawai, kurang disiplin waktu, kurang mengindahkan peraturan, kurang memelihara keindahan dan kebersihan lingkungan, perkelahian antar pelajar, narkoba, berkeliaran di jalanan, di terminal bus, di stasiun, di mall dan tempat-tempat wisata saat jam pelajaran dan sebagainya

hasil penelitian disimpulkan bahwa pemberian reward and punishment melalui tata tertib sistem point sangat efektif dalam meningkatkan kualitas karakter peserta didik dan direkomendasikan yakni 1. Pihak Madrasah, Khususnya kepala madrasah dan guru, hendaknya selalu berupaya mengevaluasi penerapan reward and punishment melaui tata tertib sistem point 2. Kementerian Agama hendaknya membuat kebijakan pada semua madrasah.3. Peserta didik penerapan reward akan memberikan semangat dan motivasi, punishment bagi peserta didik di jadikan sebagai filter atau kontrol tidak melakukan pelanggaran pada tata terib madrasah sehingga menjadi peserta didik memiliki kepribadian yang baik.
\end{abstract}

Kata Kunci: Reward, Punishment, Pendidikan Karakter, Sistem Point

\section{Pendahuluan}

Dalam UU Sisdiknas No. 20 tahun 2003 pasal 1 ayat 1 bahwa Pendidikan adalah usaha sadar dan terencana untuk mewujudkan suasana belajar dan proses pembelajaran agar peserta didik secara aktif mengembangkan potensi dirinya untuk memiliki kekuatan spiritual keagamaan, pengendalian diri, kepribadian, 
kecerdasan, akhlak mulia, serta keterampilan yang diperlukan dirinya, masyarakat, bangsa dan Negara, didalamnya terkandung harapan-harapan yang sangat mulia yaitu terciptanya peserta didik yang " memiliki keuletan spiritual, keagamaan, pengendalian diri, kepribadian yang baik serta akhlak yang mulia". ${ }^{1}$ Sedangkan dalam pandangan Islam, pendidikan karakter identik dengan pendidikan akhlaq.Walaupun pendidikan akhlaq sering disebut tidak ilmiah karena terkesan sekuler, namun sesungguhnya antara karakter dengan spiritualitas memiliki keterkaitan yang erat.

Dalam kacamata Islam secara historis pendidikan karakter merupakan misi utama para nabi. Muhammad Rasulullah sedari awal tugasnya memiliki suatu pernyataan yang unik, bahwa dirinya diutus untuk menyempurnakan karakter (akhlak). Manifesto Muhammad Rasulullah ini mengindikasikan bahwa pembentukan karakter merupakan kebutuhan utama bagi tumbuhnya cara beragama yang dapat men-ciptakan peradaban. Pada sisi lain, juga menunjukkan bahwa masing-masing manusia telah memiliki karakter tertentu, namun belum disempurnakan. $^{2}$

Namun demikian kenyataannya masalah besar yang melanda dunia pendidikan kita saat ini adalah menurunnya tatakrama kehidupan sosial dan etika moral menimbulkan ekses negatif yang merisaukan masyarakat seperti banyaknya penyimpangan- penyimpangan tingkah laku peserta didik. Penyimpangan berbagai norma agama dan sosial kemasyarakatan dalam bentuk kurang hormat pada guru dan pegawai, kurang disiplin waktu, kurang mengindahkan peraturan, kurang memelihara keindahan dan kebersihan lingkungan, perkelahian antar pelajar, narkoba, berkeliaran di jalanan, di terminal bus, di stasiun, di mall dan tempat-tempat wisata saat jam pelajaran dan sebagainya. Kondisi ini harus segera diantisipasi karena hal ini akan mengancam generasi muda bangsa kita khususnya dan tata kehidupan masyarakat umumnya. ${ }^{3}$

Hukuman merupakan salah satu alat yang digunakan untuk meningkatkan perilaku yang diinginkan dan mengurangi perilaku yang tidak diinginkan. Madrasah harus membuat jera para peserta didik yang telah melanggar peraturan madrasah dengan berbagai cara. Sebab penegakan disiplin dengan cara punishment (hukuman fisik) menjadi tidak wajar dilakukan saat ini di madrasah atau di madrasah dengan alasan melanggar hak azasi manusia. Misalnya ketika ada guru yang mencubit, padahal maksudnya adalah mengingatkan peserta didik, tetapi bisa dijerat karena termasuk bentuk kekerasan dengan menggunakan dasar UU No 23/2002 tentang Perlindungan Anak. Disebutkan dalam UU itu, anak harus mendapatkan perlindungan salah satunya dari kekerasan.

Dari kutipan di atas madrasah dirasa perlu mencari solusi terhadap permasalahan yang sedang marak terjadi. Madrasah harus membuat hukuman positif yang efeknya tetap membuat jera para peserta didik pelanggar tata tertib

\footnotetext{
${ }^{1}$ Departemen Agama RI Direktorat Jenderal Pendidikan Agama Islam,(Undang-Undang Republik Indonesia Nomor 20 Tahun 2013 tentang Sisdiknas serta Undang-Undang Republik Indonesia Nomor 14 Tahun 2005 tentang Guru dan Dosen), 2007 h. 2

${ }^{2}$ Bambang Q-Anees dan Adang Hambali, Pendidikan Karakter Berbasis Al-Qur'ân, (Bandung: PT. Simbiosa Rekatama Media, 2008), h. 100

${ }^{3}$ Ibid, h. 57
} 
madrasah. Salah satunya dengan menerapkan sistem poin. Sistem point adalah suatu kebijakan yang diambil madrasah guna mengembangkan karakter peserta didik.

Madrasah yang telah menggunakan sistem point dalam tata tertibnya yaitu Madrasah Aliyah. Al-Hikmah Bumela merupakan salah satu Madrasah Aliyah yang ada di Kabupaten Gorontalo. Kabupaten ini berada di sebelah Barat Provinsi Gorontalo. Letaknya jauh dari pusat Kabupaten dan Kota lainnya. Madrasah ini mempunyai peraturan yang cukup ketat. Terbukti dengan telah diberlakukannya sistem point pada tata tertib madrasah, yang tidak semua madrasah memberlakukannya. Di Madrasah Aliyah Al-Hikmah Bumela ini sistem point telah dijalankan akhir tahun ajaran 2012/2013. Madrasah Aliyah Al-Hikmah Bumela telah memberikan point pada setiap tata tertibnya. Point yang dicantumkan berbeda-beda sesuai dengan tingkat pelanggaran yang dilakukan. Madrasah Aliyah Al-Hikmah Bumela memberi batasan point maksimal yaitu 100. Dari judul yang ada, penulis mengembangkan melalui rumusan masalah yakni 1. Bagaimana penerapan reward and punishment melalui tata tertib sistem point dalam meningkatkan kualitas karakter peserta didik di Madrasah Aliyah AlHikmah Bumela. 2. Kendala-kendala apa yang dihadapi pihak madrasah dalam menerapkan reward and punishment melalui tata tertib sistem point dalam meningkatkan kualitas pendidikan karakter peserta didik di Madrasah Aliyah AlHikmah Bumela.

Tujuan Dalam penelitian adalah Untuk menggambarkan penerapan reward and punishment melalui tata tertib sistem point dalam meningkatkan kualitas pendidikan karakter peserta didik di Madrasah Aliyah Al-Hikmah Bumela. Penelitian ini dilakukan dengan harapan agar bisa memberikan manfaat tertentu baik bagi penulis, serta bagi pihak lain yang membutuhkan. Adapun manfaat dari penelitian ini adalah sebagai berikut : 1 . Bagi guru dan peserta didik dapat di hindari kekerasan fisik sehingga dengan adanya pemberian reward dan punishment melalui tata tertib sistem poin keharmonisan antara guru dan peserta didik terbangun dengan baik, 2.Bagi kepala madrasah dan guru, 3. Sebagai masukan bahwa penerapan reward dan punishment melalui tata tertib sistem poin sangat efektif dalam meningkatkan kualitas pendidikan karakter peserta didik di Madrasah Aliyah Al-Hikmah Bumela sehingga peran kepala madrasah dan guru sangat penting dalam mengelolahnya agar supaya ada sebuah perubahan karakter peserta didik yang lebih baik dari efek jerah atau sanksi yang di berlakukan setelah peserta didik melakukan pelanggaran.

\section{A. Konsep Reward (Penghargaan) and Punishment (Hukuman)}

Reward (Penghargaan) adalah salah satu dari kebutuhan pokok yang mendorong seseorang untuk mengaktualisasikan dirinya. Penghargaan adalah unsur disiplin yang sangat penting dalam pengembangan diri dan tingkah laku anak. Seseorang akan terus berupaya meningkatkan dan mempertahankan disiplin apabila pelaksanaan disiplin itu menghasilkan prestasi dan produktivitas yang 
kemudian mendapatkan penghargaan. ${ }^{4}$ Penghargaan merupakan hadiah terhadap hasil-hasil yang baik dari anak dalam proses pendidikan. Penghargaan merupakan hal yang menggembirakan bagi anak, dan dapat menjadi pendorong bagi belajarnya. $^{5}$

Penghargaan adalah alat untuk mendidik anak -anak supaya anak dapat merasa senang karena perbuatan atau pekerjaannya mendapat penghargaan. Penghargaan harus memiliki nilai mendidik. Mendidik disini tidak hanya dalam bidang akademik tetapi juga mendidik peserta didik dalam bertingkah laku yang baik. ${ }^{6}$

Berdasarkan pendapat diatas dapat disimpulkan bahwa penghargaan adalah suatu hal positif yang diperoleh anak karena anak telah menunjukkan suatu perbuatan yang baik. Pemberian penghargaan kepada anak akan meningkatkan perilaku yang sesuai dengan aturan yang berlaku, serta membuat anak untuk menghindari diri dari perbuatan yang tidak sesuai dengan aturan. Dengan pemberian penghargaan anak akan berusaha berperilaku disiplin.

\section{Pengertian Punishment (Hukuman)}

Hukuman sebagai tindakan yang dijatuhkan kepada anak secara sadar dan sengaja sehingga menimbulkan nestapa. Dengan adanya nestapa anak akan menjadi sadar akan perbuatannya dan berjanji di dalam hatinya untuk tidak mengulanginya. Hukuman diberikan apabila teguran dan peringatan belum mampu untuk mencegah anak-anak dalam melakukan pelanggaran. ${ }^{7}$

Menurut pandangan Islam bahwa dalam pembinaan karakter melalui punishment sangat di anjurkan, kerena karakter itu tumbuh harus di biasakan melalai aturanaturan. Di nyatakan dalam sebuah hadits Kitab Riyadh al-Shalihin hal 301:

Artinya: Dari 'Amr Ibn Syu'aib dari ayahnya dari neneknya ra. berkata: Rasulullah saw. bersabda:Perintahkan anak-anakmu untuk melakukan shalat di waktu mereka berumur tujuh tahun dan pukullah mereka, jika melalaikan shalat di waktu mereka berumur sepuluh tahun. Juga pisahkan tempat tidur mereka saat itu.(Hadis hasan, diriwayatkan oleh Abu Daud dengan isnad yang hasan) ${ }^{8}$

\section{Pengertian Pendidikan Karakter}

Dalam dunia pendidikan, terdapat istilah, yaitu paedagogie artinya pendidikan. Pedagogie berasal dari kata Yunani paedagogia yang berarti "pergaulan dengan anak-anak". " Dengan kata lain, pendidikan merupakan suatu aktivitas untuk mengembangkan seluruh aspek kepribadian manusia yang berjalan seumur hidup.

\footnotetext{
${ }^{4}$ Maria J. Wantah, Pengembangan Disiplin dan Pembentukan Moral pada Anak Usia Dini. Jakarta: Departemen Pendidikan Nasional, 2005 h. 164

5 Amir DaienIndrakusuma.. Pengantar Ilmu Pendidikan. Surabaya: Usaha Nasional, 1973, h. 147

${ }^{6}$ M. Ngalim Purwanto, Ilmu Pendidikan Teoritis dan Praktis. Bandung: Remaja Rosdakarya, 2006 h.182

${ }^{7}$ Amir Daien Indrakusuma.. Pengantar Ilmu Pendidikan. Surabaya: Usaha Nasional, 1973. h. 147

${ }^{8}$ http : //masuk surge. pusat kajian hadist.com/id/indeks/hpp/kajian/temedetail/512/ajarimereka-shalat-jika-sudah-7-tahun, diakses tanggal 23 Juli 2016

${ }^{9}$ M. Ngalim Purwanto, Ilmu Pendidikan Teoritis dan Praktis. Bandung: Remaja Rosdakarya, 2006, h. 3
} 
Sebagaimana yang diungkapkan oleh Ki Hajar Dewantara, tokoh pendidikan Indonesia; beliau mengatakan bahwa "Pendidikan adalah upaya untuk memajukan budi pekerti (kekuatan batin, karakter), pikiran (intelek) dan jasmani anak didik." Lebih jelasnya, berikut akan dipaparkan mengenai pengertian pendidikan menurut para ahli:

Adapun istilah karakter, kata karakter berasal dari bahasa latin "kharakter", "kharassein", "kharax", dalam bahasa Inggris: character dan Indonesia "karakter", Yunani character, dari charassein yang berarti membuat tajam, membuat dalam. Dan individu yang berkarakter baik ialah individu yang berusaha melakukan halhal yang terbaik terhadap Tuhan YME, dirinya, sesama, lingkungan, bangsa dan negara serta dunia internasional pada umumnya dengan mengoptimalkan potensi (pengetahuan) dirinya dan disertai dengan kesadaran, emosi, dan motivasinya (perasaannya), serta memiliki nilai-nilai seperti amanah, beriman, bertaqwa, bekerja keras, disiplin, jujur, toleransi, cermat, cerdik, dinamis, gigih, hemat, empati, bijaksana, lugas, tegas, berfikir jauh ke depan, berfikir matang, bertanggung jawab, berkemauan keras, baik sangka, pemaaf, pemurah, adil, menghargai, pengabdian, pengendalian diri, komitment, mandiri, mawas diri, ikhlas, sabar, rasa malu, rajin, ramah, rela berkorban, rendah hati, sportif, hormat, tertib, produktif, susila, tekun, tegar, tepat janji, ulet. ${ }^{10}$

Sedangkan dalam perspektif Islam karakter unggul dan mulia digambarkan dengan akhlak Nabi Muhammad SAW yang termanifestasi dalam semua perkataan, perbuatan, dan persetujuan Nabi. Akhlak unggul Nabi antara lain; benar (ash-shidq), cerdas (al-fathanah), amanah (al-amanah), menyampaikan (attabligh), komitmen yang sempurna (al-iltizam), berakhlaq mulia ('ala khuluqin 'azhiim), dan teladan yang baik (uswatun hasanah). Sehingga Nabi Muhammad SAW merupakan Nabi paripurna sebagai teladan bagi seluruh umat Islam. Karakter mulia tersebut juga tercermin ke dalam perangai Nabi, Rosul, dan orang saleh sebelum Nabi Muhammad. Juga pada sikap para sahabat, tabi'in, ulama, dan tokoh yang senantiasa mengikuti jalan kebenaran yang telah digariskan Allah SWT. ${ }^{11}$.

\section{Pengertian Tata Tertib Barbasis Sistem Point.}

Tata tertib sistem point adalah kumpulan aturan-aturan yang dibuat secara tertulis dan mengikat anggota masyarakat. ${ }^{12}$ Tata tertib adalah aturan-aturan yang dibuat oleh madrasah, yang bertujuan untuk menciptakan suasana tenang dan nyaman saat kegiatan pembelajaran. ${ }^{13}$ Tata tertib adalah beberapa peraturan atau norma yang mengharuskan para peserta didik serta pendidik mematuhinya. ${ }^{14}$

\footnotetext{
${ }^{10}$ Abdul Majid \& Dian Andayani ,Pendidikan Karakter Perspektif Islam, (Bandung : PT REMAJA ROSDAKARYA. 2011), h. 45

${ }^{11}$ Tim P3KMI. Muslim Integral; Buku Program Pendampingan Pengembangan Kepribadian Muslim Integral (P3KMI). Yogyakarta:, 2012: h.42.

${ }^{12}$ Mulyono, Kesadaran Berbangsa. Bandung: Angkasa 2000: h.14

${ }^{13}$ Slamet dkk, Pendidikan Kewarganegaraan 3. Jakarta: Pusat Perbukuan Departemen Pendidikan Nasional 2008: h. 32

${ }^{14}$ Murniatmo, o dkk. Aktualisasi Nilai Budaya Bangsa di Kalangan Generasi Muda Daerah Istimewa Yogyakarta. Yogyakarta: Departemen Pendidikan dan Kebudayaan 1999: h. 47
} 
Sesuai yang dimaksud menteri pendidikan dan kebudayaan tanggal 1 mei 1974 no.14/U/19874 adalah tata tertib sekolah adalah ketentuan - ketentuan yang mengatur kehidupan sekolah sehari-hari dan mengandung sanksi bagi pelanggarnya. ${ }^{15}$ Menurut Nawawi, peserta didik adalah anak-anak yang sedang tumbuh dan berkembang baik secara fisik maupun psikologis dalam rangka mencapai tujuan pendidikan melalui lembaga pendidikan formal. Jadi secara umum tata tertib peserta didik adalah peraturan yang baik dan merupakan hasil pelaksanaan yang konsisten dari peraturan yang ada harus dipatuhi oleh peserta didik.

\section{Faktor-Faktor yang Mempengaruhi Pengembangan Pendidikan Karakter di MA.}

Perilaku menyimpang yang dilakukan oleh peserta didik tidak terjadi begitu saja tanpa ada sebab-sebab yang menyertainya, karena perilaku menyimpang berkembang melalui suatu periode waktu-waktu tertentu sebagai hasil dari serangkaian tahapan interaksisosial dan adanya kesempatan untuk berperilaku menyimpang.

Di tinjau dari sudut pandang sosiologi bahwa teori perilaku menyimpang, yaitu 1. Teori Pergaulan Berbeda, 2.Teori Labelling, 3. Teori Fungsi

\section{Teori Pergaulan Berbeda (Differential Association)}

Teori ini dikemukakan oleh Edwin H. Sutherland. Menurut teori ini, penyimpangan bersumber dari pergaulan dengan sekelompok orang yang telah menyimpang. Penyimpangan diperoleh melalui proses alih budaya (cultural transmission). Melalui proses ini seseorang mempelajari suatu subkebudayaan menyimpang (deviant subculture).

Contohnya perilaku siswa yang suka bolos sekolah. Perilaku tersebut dipelajarinya dengan melakukan pergaulan dengan orang-orang yang sering bolos sekolah. Melalui pergaulan itu ia mencoba untuk melakukan penyimpangan tersebut, sehingga menjadi pelaku perilaku menyimpang.

\section{Teori Labelling}

Teori ini dikemukakan oleh Edwin M. Lemert. Menurut teori ini, seseorang menjadi penyimpang karena proses labelling yang diberikan masyarakat kepadanya. Maksudnya adalah pemberian julukan atau cap yang biasanya negative kepada seseorang yang telah melakukan penyimpangan primer (primary deviation) misalnya pencuri, penipu, pemerkosa, pemabuk, dan sebagainya. Sebagai tanggapan terhadap cap itu, si pelaku penyimpangan kemudian mengidentifikasikan dirinya sebagai penyimpang dan mengulangi lagi penyimpangannya sehingga terjadi dengan penyimpangan sekunder (secondary deviation). Alasannya adalah sudah terlanjur basah atau kepalang tanggung.

3. Teori Fungsi

Teori ini dikemukakan oleh Emile Durkheim. Menurut teori ini, keseragaman dalam kesadaran moral semua anggota masyarakat tidak dimungkinkan karena

\footnotetext{
${ }^{15}$ Hadari nawawi, Administrasi sekolah, (Jakarta: Ghali Indonesia, 1986) h.206
} 
setiap individu berbeda satu sama lain. Perbedaan-perbedaan itu antara lain dipengaruhi oleh faktor lingkungan, fisik, dan keturunan.

Oleh karena itu dalam suatu masyarakat orang yang berwatak jahat akan selalu ada, dan kejahatanpun juga akan selalu ada. Durkheim bahkan berpandangan bahwa kejahatan perlu bagi masyarakat, karena dengan adanya kejahatan, maka moralitas dan hukum dapat berkembang secara normal.

\section{A. Penerapan reward and punishment melalui tata tertib sistem point dalam meningkatkan kualitas pendidikan karakter peserta didik di Madrasah Aliyah Al-Hikmah Bumela}

Sebelum penulis membahas bagaimana penerapan reward and punishment melalui tata tertib sistem poin dalam meningkatkan kualitas pendidikan karakter peserta didik di Madrasah Aliyah Al-Hikmah Bumela, terlebih dahulu menyampaikan kondisi madarasah Madrasah Aliyah Al-Hikmah Bumela dari sejak berdiri pada tahun 2007 s.d 2011 sesuai hasil wawancara seorang guru yang mengabdi sejak berdirinya madrasah, yang pada saat itu Madrasah Aliyah AlHikmah Bumela belum memilki panduan untuk memperbaiki karakter peserta didik, sehingga banyak pelanggaran-pelanggaran yang dilakukan oleh peserta didik, baik keterlambatan datang ke madarasah pada jam-jam 09.00 begitu pulang sebelum waktunya, membolos, sering tidak masuk kelas, keluar kelas ataupun madrasah tanpa ijin, tidak memakai seragam, memakai anting-anting bagi pria dan parahnya ada peserta didik yang meminum-minuman keras dan pelanggaran lainnya yang sudah tertuang tata tertib. Pelanggaran ini dilakukan hampir seluruh peserta didik terutama laki-laki, dan juga sering terjadi kesalahpahaman antara orang tua dan pihak madarasah dalam mengambil sebuah kebijakan. ${ }^{16}$

Memperhatikan kondisi madrasah seperti itu Kepala Madrasah Bumela mengambil kebijakan untuk dibentuklah penerapan reward and punishment melalui tata tertib sistem point di Madrasah Aliyah Al-Hikmah Bumela pada akhir tahun pelajaran 2012-2013 .

\section{Penerapan Reward And Punishment melalui tata tertib sistem point}

Penerapan reward berupa, pujian dilaksanakan kapan saja pada saat peserta didik melakukan hal yang baik yang tidak bertentangan dengan tata tertib. Pujian dapat berupa kata-kata seperti : baik, bagus, bagus sekali, dan sebagainya. Disamping berupa kata-kata, pujian dapat pula berupa isyarat-isyarat atau pertanda-pertanda. Misalnya dengan menunjukkan ibu jari (jempol), dengan menepuk bahu anak, dengan tepuk tangan, dan sebagainya. Kemudian untuk penghormatan dan hadiah dilaksanakan setiap semester pada saat penyerahan laporan hasil belajar peserta didik baik pada semester ganjil maupun genap. Penghargaan yang berbentuk penghormatan berbentuk penobatan yaitu anak mendapat penghormatan seperti dihadapan teman-teman sekelas, teman-teman madrasah, atau mungkin juga di hadapan teman dan orang tua peserta didik. Misalnya pada acara pembagian raport diumumkan dan ditampilkan peserta didik

\footnotetext{
${ }^{16}$ Wawancara seorang guru yang mengabdi sejak tahun 2007 (Ibu Sri Hantuti Lihawa, S.P'd.I) tgl 02 Mei 2016
} 
yang memiliki kepribadian yang baik dengan memberikan penghargaan berbentuk piagam atau piala. Selanjutnya penghargaan berbentuk yakni penghargaan yang berbentuk barang. Penghargaan yang berbentuk barang ini disebut penghargaan materil. Hadiah yang berupa barang ini dapat terdiri dari keperluan madrasah, seperti buku pelajaran, uang, peralatan sholat, dan sebagainya.

Sebelum penulis menyampaikan gambaran tentang penerapan punishment melalui tata tertib sistem point di Madrasah Aliyah Al-Hikmah Bumela, penulis menjelaskan secara singkat proses pemberlakuan punishment melalui tata tertib sistem point. Sebelum tata tertib dilaksanakan telebih dahulu sudah melalui pembahasan atau kesepakatan antara pihak madrasah, orang tua dan peserta didik setiap tahun ajaran baru. Yang di maksud punishment adalah sanksi yang diberikan setiap saat kepada peserta didik yang melakukan pelanggaran berupa pemberian point atau angka dengan batasan-batasan sesuai dengan jenis pelanggaran dan klasifikasi dan di lanjutkan dengan pembinaan secara bertahap sesuai dengan batasan kriteria yang sudah ditentukan pada tata tertib. Contoh : peserta didik berkelahi main hakim sendiri maka kedua peserta didik di beri punishment yakni dengan denda point terendah 25 dilanjutkan dengan pembinaan yakni di peringatkan, membuat surat pernyataan yang di tandatangani orang tua, wali kelas dan kepala madrasah.

Punishment diberikan pada peserta didik yang melanggar tata tertib madrasah atau kompensasi yang harus dilaksanakan terhadap suatu pelanggaran. Hal ini dipertegas oleh Ibu Jarni Hasan Rifai, S.Ag selaku wakamad kesiswaan. "Reward itu untuk penghargaan terhadap peserta didik yang tidak melakukan pelanggaran tata tertib madrasah, sedangkan punishment untuk peserta didik yang melanggar tata tertib madrasah atau kompensasi yang harus dilaksanakan terhadap suatu pelanggaran. Penerapan atau metode ini menurut saya selaku wakamad kesiswaan sangat baik dan sangat setuju karena dengan adanya reward and punishment memotivasi peserta didik untuk bisa maju dan lebih baik, agar bisa tertib, disiplin dalam mematuhi peraturan yang ada dalam madrasah, dengan diterapkanya sistem ini supaya peserta didik lebih berakhlak baik, dari hasil evaluasi dan data 3 tahun terakhir menunjukkan bahwa peningkatan karakter peserta didik dari tahun ketahun ada sebuah perubahan sangat signifikan dan pelanggaran menurun karena dengan adanya pemberian reward and punishment peserta didik bisa mematuhi peraturan madrasah. Data rekapitulasi yang diambil dari buku kontrol peserta didik pada Tahun Pelajaran 2013-2014 sampai 2015-2016 baik kelas X.XI.XII dari jenis pelanggaran sesuai klsaifikasi baik A,( Berat Sekali), B (Berat), C (Sedang) dan D (Ringan) sejumlah 44 item hanya 13 item pelanggaran yang dilakukan oleh peserta didik. Melihat data pelanggaran tersebut yang dominan di lakukan oleh peserta didik.

Berdasarkan tabel 3 dan 4 klasifikasi, presentasi jumlah serta jenis pelanggaran dan jumlah peserta didik memperoleh reward serta jumlah peserta didik memperoleh punishment/DO (pindah madrasah), di Madrasah Aliyah AlHikmah Bumela selama kurun waktu 2013 sampai dengan 2016 dapat di jelaskan hal-hal sebagai berikut :

Hasil keterangan yang di dapat dari wakamad kesiswaan bahwa : 
a. Tingginya pelanggaran di lakukan oleh peserta didik pada tahun 2013-2014 sesuai tabel di atas :

> Pada tahun 2013-2014 kerlambatan peserta didik mengikuti apel pagi sangat tinggi sekitar $90 \%$ di akibatkan; Tidak adanya transportasi ke madrasah baik itu transportasi umum maupun pribadi, maka pada tahun 2014-2015 lembaga mencari solusi yakni menyediakan mobil operasional madrasah yang dimanfaatkan untuk menjemput dan mengantar peserta didik, sehinganya pada tahun 2014 s.d 2016 keterlambatan peserta didik menurun, sekalipun masih ada yang terlambat disebabkan oleh faktor kebiasaan dari peserta didik terlambat bangun, malas dan ini hanya dilakukan orang yang sama.

$>$ Pelanggaran yang lain adalah peserta didik tidak memakai seragam sesuai dengan ketentuan madrasah pertama; dipengaruhi kondisi ekonomi orang tua yang rendah karena ada orang tua peserta didik pekerjaan meraka petani bahkan ada peserta didik orang tuanya broken hoom. Kedua di pengaruhi oleh trend model jaman.

> Selanjutanya, masih tingginya peserta didik tidak melaksanakan sholat dzuhur berjamaah. Hal ini terjadi karena belum ada pembiasaan sebelumnya, sehingganya pada tahun 2013-2014 setelah di bentuknya tata tertib madrasah salah satunya adalah kewajiban bagi peserta didik untuk sholat zhuhur barjamaah ini sangat berat bagi mereka, tetapi dengan adanya reward and punishment maka mereka sudah mulai terbiasa melaksanakan sholat zhuhur bersama

a. Tahun 2013-2014 sejumlah 2 orang peserta didik yang dikembalikan keorang tua dan tahun 2015-2016 sejumlah 5 orang, karena mereka melakukan pelanggaran berulang kali dan sudah di komunikasikan dengan orang tua dan sudah mencapai point 100 dan ada pesrta didik di kembalikan keorang tua bukan karena punishment point mencapai 100 tetapi melakukan perbuatan seperti amoral.

b. Selanjutnya dalam pemberian reward pada tahun 2013-2014, jumlah peserta didik 47 orang, sebanyak 45 mendapatkan reward, tahun 2014-2015 jumlah peserta didik 49 orang, sebanyak 42 mendapatkan reward, tahun 2015-2016 jumlah peserta didik 50 orang, sebanyak 45 mendapatkan reward

Hal ini dipertegas dengan jawaban dari peserta didik perwakilan pengurus Osis yang bernama Anindita Tomayahu sebagai berikut. "pemberian reward and punishment melalui tata tertib sistem point saya tahu sejak masuk sebagai peserta didik di Madrasah Aliyah Al-Hikmah Bumela, Saya setuju dan tertarik dengan penerapan pemberian reward and punishment melalui tata tertib sistem point di madarasah, dengan adanya reward maka kami peserta didik akan lebih bersemangat dalam berprestasi dan selalu mematuhi peraturan madrasah sehingga menjadi orang yang memiliki kepribadian yang baik, dengan adanya punishment setiap hari maka peserta didik akan berpikir dua kali atau ada perasaan takut untuk melakukan pelanggaran kembali, dan harapannya saya kedepan bahwa pemberian rewardnya lebih bagus lagi, karena selama ini reward yang kami rasakan hanya sebatas pujian ataupun hadiah hanya berupa peralatan belajar atau sholat, kedepannya reward seperti pemberian beasiswa supaya lebih memotivasi 
kami sebagai peserta didik untuk mematuhi peraturan madrasah dan bersemangat meraih prestasi dan mengenai punishment perlu sosialisasi dipermantap lagi terutama awal peserta didik masuk di madrasah atau selama berada di lingkungan madarasah peraturan-peraturan yang tertuang dalam tata tertib sistem point dan selalu mengingatkan setiap hari pada setiap apel pagi atau pulang, sehingga menurunnya jumlah peserta didik yang terkena punishment dan nama baik madrasah selalu terjaga dengan baik ${ }^{17}$

Selanjutnya peneliti melanjutkan wawancara kepada informan yang lain sesuai dengan keterangan seorang guru atas nama Ibu Yusri Mardjun, sebagai berikut : Latar belakang pemberian reward and punishment melaui tata tertib sistem poin karena melihat kondisi peserta didik jauh dari harapan yang kita inginkan terutama dari perbaikan karakter peserta didik, Dengan reward and punishment para guru berkeinginan adalah untuk memberikan penghargaan bagi peserta didik yang yang tidak melakukan pelanggaran terhadap tata tertib madarasah terutama dalam kegiatan proses pembelajaran dan jika memberikan sanksi/hukuman berdasarkan data yang objektif.

Dengan adanya reward dan punishment diupayakan untuk menyeimbangkan perlakuan terhadap yang melanggar atau perlakuan terhadap yang berprestasi dan memotivasi peserta didik lebih displin, menurut saya penerapan reward and punishment pada tata tertib sistem point sangat bagus karena dengan penerapan reward and punishment peserta didik lebih disiplin, bertanggung jawab dan lebih giat belajar, alasannya saya penerapan reward and punishment pada tata terib sistem point pada madarash sangatlah membawa perubahan positif bagi peserta didik, karena pada dasarnya peserta didik yang sering terlambat dan sering bolos, tidak sholat, tidak mengerjakan tugas dan melakukan pelanggaran lainnya dengan diterapkanya reward and punishment pada tata terib sistem point peserta didik tidak melakukan perbuatan hal yang sama dan mereka berlomba untuk menjadi peserta didik terbaik di madrasah sehingga mendapatkan reward. Saya juga tertarik dengan penerapan reward and punishmnet ini dengan peraturan ini banyak manfaat yang kita dapati yakni semakin berkurangnya peserta didik yang melanggar perturan madrasah, prestasi peserta didik meningkat dan lebih dari sangat memudahkan guru untuk membimbing peserta didik yang sering melakukan pelanggaran. Sebelum pemberlakuan penerapan reward and punishment banyak peserta didik yang melakukan

Pernyataan lain dikemukakan oleh Bapak Yelfis djamaludin, S.Pd.I selaku wali kelas XI sebagaimana berikut : "Di Madrasah Aliyah Al-Hikmah Bumela sering kali terjadi pelanggaran yang dilakukan peserta didik dan atas pelanggaran tersebut yang berulang-ulang itulah menjadi sebab perlunya diberikan reward and punishment melalui tata tertib sistem point, kemudian alasan yang sangat mendasar dterapkanya reward and punishment melalui tata tertib sistem point adalah banyaknya pengeluhan guru atas pelanggaran peserta didik dan tidak dapat diatasi dengan teguran saja. Dengan diterapkanya reward and punishment melalui tata tertib sistem point terlihat secara signifikan bahwa menurunya pelanggaran

\footnotetext{
${ }^{17}$ Hasil Wawancara pengurus Osis; Anindita Tomayahu tanggal 31 Mei 2016
} 
peserta didik dan peserta didik bangga mendapatkan penghargaan dengan tidak melakukan pelanggaran. Saya selaku wali kelas setuju dan terlebih dukungan positif semua guru, dari peserta didik dan orang tua atas penerapan reward and punishment melalui tata tertib sistem point artinya dengan penerapan sistem ini peserta didik akan mempertimbangkan apa yang meraka lakukan dimadrasah. ${ }^{18}$

Kemudian keterangan yang sama dari Wali Kelas X, ibu Sri Hantuti Lihawa, S.Pd.I bahwa setelah di bentuknya reward and punishment maka pelanggaran peserta didik menurun prestasi meningkat dan dengan adanya reward and punishment perubahan karakter peserta didik sangat nampak perubahannya, ini tidak terlepas adanya dukungan positif dari peserta didik dan orang tua dalam penerapan pemberian reward and punishment melalui tata tertib sistem point, kalaupun masih ada peserta didik mengeluh tentang pemberlakuan punishment. ${ }^{19}$

Dari temuan hasil penelitian baik yang diperoleh dari data dokumen madrasah dan hasil wawancara, sebagai peneliti menyimpulkan bahwa : pertama penerapan reward and punishment melalui tata tertib sistem point sangat efektif dalam meningkatkan karakter peserta didik, meningkatkan prestasi, dan juga menumbuhkan kesadaran peserta didik untuk mentaati peraturan madrasah walaupun masih ada yang melakukan pelanggaran, kedua bentuk penyimpangan atau pelanggaran di sebabkan, faktor ekonomi orang tua rendah, faktor keluarga broken hoom dan factor kurang kesadaran dari peserta didik itu sendiri.

B. Kendala madrasah setelah menerapkan reward and punishment melalui tata tertib sistem point dalam meningkatkan kualitas pendidikan karakter peserta didik di Madrasah Aliyah Al-Hikmah Bumela

Dalam pembahasan ini di uraikan temuan hasil penelitian yang telah dilakukan dilapangan yaitu membahas tentang gambaran kendala madrasah setelah menerapkan reward and punishment melalui tata tertib sistem point dalam meningkatkan kualitas pendidikan karakter peserta didik di Madrasah Aliyah AlHikmah Bumela. pada bab sebelumnya walaupun hasil penelitian menunjukkan bahwa penerapan reward and punishment melalui tata tertib sistem point dapat meningkatkan kualitas pendidikan karakter peserta didik. Namun tidak menutup kemungkinan masih ada yang perlu di perbaiki setelah melihat kekurangankekurangan dalam pelaksanaan penerapan reward and punishment melalui tata tertib sistem point.

Dari hasil penelitian ini melalui wawancara diketahui bahwa kendala yang dihadapi oleh madrasah. sesuai dengan keterangan Ibu Jarni Hasan Rifai, S.Ag selaku Wakamad Kesiswaan adalah kendala pelaksanaan penerapan reward and punishment melalui tata tertib sistem point seperti:

Pertama; kurang telitinya setiap pencatatan atau pendataan setiap kejadian oleh guru piket ini di akibatkan guru piket bersamaan dengan jadwal mengajar, $k$

Kedua: rendahnya kepedulian sebagian orang tua terhadap anaknya contoh ketika orang tua diundang kemadrasah untuk memberitahukan pelanggaran, orang tua tidak memenuhi undangan,

\footnotetext{
${ }^{18}$ Hasil wawancara : Bapak Yelfis Djamaludin, S.Pd.I tanggal 31 Mei 2016

${ }^{19}$ Hasil wawancara : Ibu Sri Hantuti Lihawa, S.Pd.I tanggal 31 Mei 2016
} 
Ketiga: kurangnya kesadaran peserta didik dan pemahaman terhadap penerapan reward and punishment melalui tata tertib sistem point kalaupun sudah dijelaskan dan dingatkan berulang-ulang oleh guru atau piket. Kesadaran pada dasarnya lahir dari niat yang sungguh-sungguh dalam hati individu. Begitu pula karakter yang sebenarnya lahir dari masing-masing individu peserta didik yang sadar akan pentingnya memiliki karakter disiplin dan tanggung jawab dalam kehidupan sehari-hari. Kurangnya kesadaran diri peserta didik Madrasah Aliyah Al-Hikmah Bumela akan pentingnya pemberian reward and punishment melalui tata tertib sistem point di madrasah terlihat dari masih ada beberapa peserta didik yang terlambat apel, keluar kelas ketika jam guru di dalam kelas, tidak memakai seragam sesuai ketentuan. Kemudian melalui informan lainnya yakni Bapak Yelfis Djamaludin, S.Pd.I selaku wali kelas XI, Ibu Sri Hantuti Lihawa, S.Pd.I selaku wali kelas X dan Ibu Yusri mardjun, S.Pd.I bahwa kendala lainya adalah pengeluhan peserta didik terhadap pemberlakuan punishment hampir-hampir mereka putus asa terutama pada peserta didik baru kelas $\mathrm{X}$ yang notabene peserta didik masih butuh beradaptasi.

Keempat, pengaruh lingkungan pergaulan peserta didik. Lingkungan di luar keluarga dan madrasah sering kali menjadi faktor penghambat dalam membangun kedisiplinan dan tanggung jawab peserta didik di madrasah. Lingkungan pergaulan peserta didik di luar madrasah sangat rentan dan berpengaruh dalam pembentukkan karakter pada dirinya. Peserta didik yang bergaul dengan lingkungan yang kurang menerapkan aturan secara tegas atau bahkan mengabaikan aturan tidak menutup kemungkinan akan membawa dampak negatif pada perilaku peserta didik ketika berada di lingkungan madrasah. Sehingga peran orang tua baik di rumah maupun guru yang menjadi orang tua di madrasah sangat diperlukan untuk memberikan pengarahan kepada peserta didik agar berhati-hati dalam memilih teman.

Kelima, kurangnya sikap keteladanan beberapa guru dalam ketepatan datang ke madrasah. Keteladanan guru di madrasah sangat berpengaruh pada sikap dan perilaku peserta didiknya. Ketidaktepatan beberapa guru datang ke madrasah yang dilihat oleh peserta didik akan menjadikan peraturan tata tertib peserta didik dalam hal masuk madrasah kurang berjalan efektif.

\section{Upaya Madrasah Mengatasi Mengatasi Kendala setelah Menerapkan Reward And Punishment melalui Tata Tertib Sistem Poin dalam Meningkatkan Kualitas Pendidikan Karakter Peserta Didik di Madrasah Aliyah Al-Hikmah Bumela.}

Berdasarkan kenyataan di lapangan menunjukkan bahwa masih ditemukan kendala dalam penerapan reward and punishment melalui tata tertib sistem poin dalam pembentukan karakter peserta didik, sehingga ada upaya untuk mengatasi kendala yang dialami tersebut yakni :

Pertama, mengatur jadwal pembelajaran dengan guru piket, sehingga tidak terjadi jadwal bersamaan dan ini salah satu solusi agar tugas guru piket lebih optimal dalam mengontrol setiap pelanggaran yang dilakukan oleh peserta didik dan Upaya yang lain juga dilakukan dengan memperbaiki administrasi piket guru dengan menambah data selengkap mungkin seperti membuat tabulasi/grafik daftar 
keterlambatan peserta didik dan pelanggaran lainnya serta meningkatkan kinerja tim tata tertib sehingga dapat dijadikan sebagai bahan untuk mengevaluasi.

Kedua, komunikasi antar warga madrasah. Komunikasi diperlukan dalam rangka menjaga hubungan baik antara pihak yang terlibat dalam membangun disiplin dan tanggung jawab peserta didik. Sebab keterlibatan kepala madrasah, guru, dan orang tua peserta didik sangat besar dalam menentukan keberhasilan pendidikan karakter. Komunikasi dapat dilaksanakan melalui sosialisasi tata tertib kepada seluruh warga madrasah. Sosialisasi bisa diberikan ketika kegitan MOS, upacara bendera, kegiatan bersama di aula, ketika sholat ja'mah, di kelas maupun secara langsung diberika kepada peserta didik yang bermasalah dengan tata tertib agar mengingat kembali bentuk peraturan yang diterapkan di madrasah.

Ketiga, memberikan pembinaan kepada peserta didik yang bermasalah dengan tata tertib oleh guru atau wali kelas dengan mendatangkan orang tua. Pembinaan merupakan langkah awal yang dilakukan untuk peserta didik yang bermasalah dengan tata tertib agar dapat memecahkan masalah yang dihadapi dan tidak mengulangi kesalahan yang sama. Pembinaan dilakukan bertahap oleh guru yang bersangkutan yang mengetahui kesalahan peserta didik, selanjutnya apabila kesalahan peserta didik mendapat bobot point yang lebih tinggi, , kemudian wakil kepala madrasah bidang kesiswaan dengan mendatangkan orang tua. Mengajak orang tua peserta didik bekerja sama dengan pihak madrasah dalam hal pembentukan disiplin peserta didik dan juga mengontrol perilaku peserta didik sehari-hari. Kerjasama antara pihak madrasah dengan orang tua dalam mengontrol perilaku peserta didik harus dibina secara intensif.

Keempat, yakni pembiasaan disiplin dari orang tua ketika di rumah. Seharusnya orang tua selalu membiasakan anak-anaknya untuk selalu menanamkan kedisiplinan ketika di rumah misalnya orang tua mengajak anak untuk selalu bangun tepat waktu, shalat tepat waktu, melakukan tugas rumah dengan baik dan hal ini bisa didukung dengan pembuatan aturan seperti jadwal sehari-hari yang berisi tugas masing-masing anggota keluarga. Apabila kebiasaan kita dikendalikan oleh aturan dan itu dilakukan secara tertib dan teratur maka disiplin akan terbentuk dengan sendirinya, karena disiplin itu memerlukan proses dan waktu yang lama. Pembiasaan yang dilakukan secara terus-menerus dan berulang-ulang maka akan menghasilkan disiplin yang kuat. Terbentuknya karakter memerlukan proses relatif lama dan terus menerus. Kegiatan pembiasaan secara spontan dapat dilakukan misalnya menyapa, baik antar teman, antar guru maupun antar guru dengan peserta didik. Pembiasaan diarahkan terhadap upaya pembudayaan pada aktivitas tertentu sehingga menjadi aktivitas yang terpola. Melalui pelaksanaan tata tertib sistem point dapat dilatihkan dan diterapkan kepada peserta didik untuk membiasakan diri bersikap disiplin secara terpola. Dengan adanya pembiasaan yang terus menerus nantinya akan dapat menjadi sebuah budaya yaitu budaya yang menjunjung tinggi kedisiplinan sehingga nantinya tidak akan menjadi generasi penerus bangsa yang tidak tahu aturan dan berbuat semaunya sendiri. Pembiasaan di Madrasah Aliyah Al-Hikmah Bumela ini dilakukan dengan menerapkan budaya pada semua warga madrasah yakni menebar senyum, mengucapkan salam, bertegur sapa, berperilaku sopan, dan juga bertindak santun. Guru juga membiasakan peserta didik untuk menghormati orang 
yang lebih tua dengan bertegur sapa dan mengucap salam ketika bertemu serta menghargai teman madrasah dengan tidak memilih-milih teman dan mau menghargai pendapat satu sama lain ketika belajar di kelas.

Kelima, kurangnya hubungan guru serta wali kelas dengan peserta didik terutama peserta didik yang bermasalah terhadap tata tertib. Dalam membentuk disiplin peserta didik, pihak konselor kurang melakukan pendekatan secara intensif dengan peserta didik terutama peserta didik yang bermasalah karena konselor disini memiliki tugas untuk memberikan pencerahan serta membantu memecahkan masalah peserta didik. Kemudian hubungan antara wali kelas dengan peserta didik juga masih kurang karena wali kelas yang bertugas mengontrol kondisi anak-anak kelas yang dipimpinnya.

Keenam, upaya yang dilakukan oleh madrasah untuk kehadiran guru bisa tepat waktu yakni madrasah memberlakukan daftar hadir melalui pinger print agar kiranya guru berusaha tidak terlambat karena dengan adanya pinger print kehadiran tidak bisa di manifulasi.

\section{Kesimpulan}

Penerapan reward and punishment melalui tata tertib sistem point sangat efektif dalam meningkatkan kualitas pendidikan peserta didik di Madrasah Aliyah Al-Hikmah Bumela. Hasil analisis atau evaluasi untuk 3 tahun terakhir menunjukkan bahwa peningkatan karakter peserta didik dari tahun ketahun ada sebuah perubahan sangat signifikan dan pelanggaran menurun karena dengan adanya pemberian reward and punishment peserta didik bisa mematuhi peraturan madrasah. Data rekapitulasi yang diambil dari buku control peserta didik pada Tahun Pelajaran 2013-2014 sampai 2015-2016 baik kelas X.XI.XII dari jenis pelanggaran sesuai klsaifikasi baik A,( Berat Sekali), B (Berat), C (Sedang) dan D (Ringan) sejumlah 44 item hanya 14 item pelanggaran yang dilakukan oleh peserta didik, kalaupun masih ada pelanggaran yang dominan dilakukan peserta didik contoh dari 14 item yang ada yakni keterlambatan datang ke madrasah. upaya-upaya Pertama, mengatur jadwal pembelajaran dengan guru piket, sehingga tidak terjadi jadwal bersamaan dan ini salah satu solusi agar tugas guru piket lebih optimal. Kedua, komunikasi antar warga madrasah. Komunikasi diperlukan dalam rangka menjaga hubungan baik antara pihak yang terlibat dalam membangun disiplin dan tanggung jawab peserta didik. Ketiga. Upaya yang lain memberikan pembinaan kepada peserta didik. Keempat, pembiasaan disiplin dari orang tua ketika di rumah. Seharusnya orang tua selalu membiasakan anakanaknya untuk selalu menanamkan kedisiplinan ketika di rumah. Kelima,yakni , memberlakukan daftar hadir melalui pinger print agar kiranya guru berusaha tidak terlambat . 


\section{DAFTAR PUSTAKA}

Departemen Agama RI Direktorat Jenderal Pendidikan Agama Islam,(UndangUndang Republik Indonesia Nomor 20 Tahun 2013 tentang Sisdiknas serta Undang-Undang Republik Indonesia Nomor 14 Tahun 2005 tentang Guru dan Dosen), 2007

Q-Anees, Bambang dan Hambali ,Adang, Pendidikan Karakter Berbasis AlQur'ân, (Bandung: PT. Simbiosa Rekatama Media, 2008)

J. Wantah, Maria, Pengembangan Disiplin dan Pembentukan Moral pada Anak Usia Dini. Jakarta: Departemen Pendidikan Nasional, 2005

Daien, Indrakusuma Amir, Pengantar Ilmu Pendidikan. Surabaya: Usaha Nasional, 1973

Purwanto, M. Ngalim, Ilmu Pendidikan Teoritis dan Praktis. Bandung: Remaja Rosdakarya, 2006

http: //masuk surge. pusat kajian hadist.com/id/indeks/hpp/kajian/temedetail /512/ajari-mereka-shalat-jika-sudah-7-tahun, diakses tanggal 23 Juli 2016

Majid, Abdul \& Andayani, Dian ,Pendidikan Karakter Perspektif Islam, (Bandung : PT REMAJA ROSDAKARYA. 2011)

Tim P3KMI. Muslim Integral; Buku Program Pendampingan Pengembangan Kepribadian Muslim Integral (P3KMI). Yogyakarta:, 2012

Mulyono, Kesadaran Berbangsa. Bandung: Angkasa 2000

Slamet dkk, Pendidikan Kewarganegaraan 3. Jakarta: Pusat Perbukuan Departemen Pendidikan Nasional 2008

Murniatmo, dkk. Aktualisasi Nilai Budaya Bangsa di Kalangan Generasi Muda Daerah Istimewa Yogyakarta. Yogyakarta: Departemen Pendidikan dan Kebudayaan 1999

Nawawi Hadari, Administrasi sekolah, (Jakarta: Ghali Indonesia, 1986)

Soekanto, Soerjono, Pengantar Penelitian Hukum, Jakarta: UI-Press, 1986

Amirudin dan Asikin Zainal, Pengantar Metode Penelitian Hukum, (Jakarta: Rajagrafindo Persada, 2006)

P. Spradley, James, Metode Etnografi, 2005

Danim, Sudarwan, Menjadi Peneliti Kualitatif, (Bandung: Pustaka Setia, 2002) 
Salim Agus, Penelitian Kualitatif, (Yogyakarta: Pustaka Pelajar, 2002)

Moleong, Lexi, Metodologi Penelitian Kualitatif. Bandung : PT Remaja Rosdakarya.

Miles \& Huberman, Analisis data Kualitatif, (Jakarta: UI Press, 1992) 